\title{
A perspectiva jurídica na literatura mateana a partir da sentença de Mateus 21,43
}

\author{
Orientador: Isidoro Mazzarolo \\ Mestrando: Eliezer Alves de Assis \\ Área de Concentração: Teologia Bíblica \\ Linha de Pesquisa: Análise e Interpretação de Textos do Antigo e \\ Novo Testamento
}

A cláusula redacional de Mateus 21,43, no contexto da parábola dos vinhateiros 21,33-46, encontra-se numa questão forense. A sentença é fundamental para entender o sentido da parábola dos vinhateiros $(21,33-46)$ como parábola jurídica. Mateus indica a culpabilidade de Israel, com a sentença 21,43 (seus dirigentes) e sua imediata e inevitável condenação, com a perda da basilei,a, para logo em seguida transferi-la para um novo e;qnoj que produza frutos. Essa dinâmica é articulada em uma perspectiva de procedimento jurídico. Esta tese procura demonstrar que esta temática aponta para a concepção do sentido jurídico no Evangelho de Mateus, a partir da análise dos elementos constitutivos da sentença de 21,43. A relevância do tema está no fato de que uma análise da perspectiva jurídica na literatura mateana, torna-se possível a partir de Mateus 21,43 e que a sentença possibilita uma chave de leitura para a estrutura e para a eclesiologia mateanas.

Palavras-chave: Cláusula Redacional de Mateus 21,43; Parábola; Vinhateiros Homicidas; Eclesiologia. 